\title{
Extraction, Characterization and Health Benefit of Dietary Chili Pepper (Capsaicin): A Review of Recent Progress
}

\author{
Ngouana Moffo A. Ivane ${ }^{\text {a, } 1}$, Di Zhang ${ }^{\text {a, 1* }}$ \\ ${ }^{a}$ School of Food and Biological Engineering, Jiangsu University, Zhenjiang 212013, P. R. China \\ *Corresponding author \\ E-mail address: di.zhang[at]ujs.edu.cn \\ ${ }^{1}$ These authors contributed equally to this work and should be considered co-first authors. \\ Phone: +86-15605287157
}

\begin{abstract}
Chili peppers are widely eaten spices across the globe, and capsaicin, the major source of the spicy taste, is said to contain a variety of biological functions such as pain relief, anti-inflammation, anticancer, cardio protection, as well as weight loss. In this review, we present the recent progress in various extraction and characterization methods of chili peppers.
\end{abstract}

Keywords: Capsaicin, chili pepper, extraction, health benefits

\section{Introduction}

The Capsicum genus includes chili pepper, which is one of the world's most popular and oldest condiments, spice and vegetable. This genus contains roughly 25 species, with its origins in South and Central America, as well as Mexico (Zhang et al., 2021) . Chili pepper has indeed been utilized as, natural colorant, vegetable, and in herbal medicine from prehistoric days, and it is one of the very first plants to be cultivated on the Mexican peninsula (M. Lu et al., 2017).

Natural ingredients remain one of the most important sources of therapeutic discoveries, offering an opportunity to research essential science. Capsaicin is an active ingredient in chili peppers that causes them to have an irritant and burning sensation (Alothman et al., 2012; Jang et al., 2008; Ng \& Reuter, 2015; Seca \& Pinto, 2018; Xiang et al., 2021). This volatile component in chili peppers was originally identified more than a century ago. Notwithstanding this early accomplishment, the exact chemical structure of capsaicin was not discovered until 1923, and Finally, in 1930, Spath and Darling chemically synthesized capsaicin (Arora et al., 2021). S. Kosuge and Y. Inagaki, Japanese scientists, discovered compounds from chili pepper that was similar to capsaicin and termed them capsaicinoids in 1961 (Daood et al., 2015) . The most potent capsaicinoids are nordihydrocapsaicin, homocapsaicin, and dihydrocapsaicin, (Table.1) which have a composition of $1 \%, 7 \%$, and $22 \%$, respectively (M. Lu et al., 2017) . Capsaicin accounts for around $68 \%$ of the entire chili pepper composition and is mainly accountable for the astringency of chili peppers (Patowary et al., 2017; PeñaAlvarez et al., 2012; Stoica et al., 2016) . However, the precise proportion of other capsaicinoids and capsaicin vary based on the chili sources and method of extraction (Bajer et al., 2015; Gerardo F. Barbero et al., 2006b; Satya Prasad et al., 2004) . Ever since its discovery, capsaicin has been the subject of intense investigation due to evidence of a wide range of biological effects. Capsaicin is now being studied in Phase 3 trials studies for the treatment of postoperative complications, rheumatism, musculoskeletal problems, and chronic/acute nerve pain (Nagy et al., 2017; Xiang et al., 2021).

Despite its widespread usage, the intense spiciness limits the use of significant amounts of capsaicin in regular food and pharmaceuticals. Various researchers reported the following findings regarding the cytotoxicity of capsaicin in capsicum fruits: Capsaicin was shown to be mutagenic by Nagabhushan \& Bhide, as evidenced by Ames and micronucleus tests (Nagabhushan \& Bhide, 1986). Capsaicinoids were suspected of being a risk factor for, liver, gastric, gallbladder cancer, and duodenal stomach based on data from several animal experiments and casecontrol investigations (Agrawal et al., 1986; Lopez-Carrillo et al., 1994) . Nevertheless, research is underway to alter the capsaicin compound in order to mitigate some of the negative consequences. Several published studies have also indicated serious respiratory issues and mortality in humans exposed to intense capsaicin aerosol formulations (Braga Ferreira et al., 2020; Nagy et al., 2017; Patowary et al., 2017). According to the research literature, capsaicin is fragrant, impairs temperature regulation, causes autonomic reflexes and gastrointestinal discomfort, and is poorly absorbed. The utilization of all of capsaicin qualities resulted in the invention of pepper spray, a strong contender for thwarting uncontrollable riots and apprehending errant offenders by law enforcement authorities (M. Lu et al., 2017).

Despite its negative consequences, capsaicin has been used to treat a wide variety of medical disorders. Topical capsaicin has been studied for the treatment of chronic pain disorders such as rheumatoid arthritis, neuropathic pain, hemodialysis-associated itching, diabetic neuropathy, psoriasis, post-mastectomy neuroma, and vestibulitis (Belvisi \& Birrell, 2017) . It's also been advised as a therapy for a variety of acute disorders because continuous topical administration of capsaicin particularly promotes the secretion and inhibition of neuropeptides in polymodal Ctype, tiny myelinated A-delta-type cutaneous nerves and unmyelinated. Though capsaicin has been shown to be

Volume 11 Issue 1, January 2022 
cytotoxic (Nagabhushan \& Bhide, 1986), however, topical research using high-purity capsaicin and established methods provide evidence that capsaicin's mutagenic and cancerous capabilities are relatively low and that purified capsaicin is very important (Shin et al., 2013) . Capsaicin has also shown encouraging benefits in early studies for prostate cancer, blepharospasm, lung cancer, and many other different types of leukemia (M. Lu et al., 2017; Stoica et al., 2016) . Even though capsaicin is detrimental to one's health in a variety of ways, it cannot be denied that capsaicin has numerous therapeutic implications. However, these implications have limited their applicability in other indications due to inconsistent findings. Capsaicin, for example, has been shown to have both chemotherapeutic and chemopreventive effects (Amantini et al., 2009; K. S. Chen et al., 2015) . Furthermore, in vivo research supports capsaicin's anti-tumorigenic ability (H. F. Lu et al., 2010) . Capsaicin, as a whole, is a potential medication applicant that might one day be used as a primary treatment therapy for several metabolic ailments. In this review, we provide an up-to-date extraction and analytical method of chili pepper.

\section{Method of Extraction}

Over the last few years, many extraction techniques for capsaicinoids from spicy peppers have been established. The first step in creating an extraction process is to choose a suitable solvent that will lead to a high output of the target component. The first step in creating an extraction process is to choose a suitable solvent that will lead to a high output of the target component (Renato et al., 2019) . Methanol, acetonitrile, water, and ethanol are the most often used solvents for extracting capsaicinoids (Slack, 2016). In addition to the solvent selection technique, several other influential aspects must be addressed in order to attain maximum extraction yields, such as extraction duration, temperature, solvent volume, method reproducibility, and repeatability. Researchers have extensively used extraction methods such as magnetic stirring, maceration, enzymatic extraction, microwave-assisted extraction (MAE), ultrasound-assisted extraction (UAE), pressurized liquid extraction (PLE), supercritical fluid, and Soxhlet extraction.

\subsection{Soxhlet extraction}

A soxhlet operation is a classic approach that is commonly used to extract oil from organic matrices. It is utilized whenever the target molecule has minimal solubility in a solvent, whereas the contaminants are insoluble in this solvent (Arora et al., 2021; M. Lu et al., 2017) . Bajer et al successfully isolated capsaicinoids from a variety of chili samples using the soxhlet technique with methanol as the main solvent over a timeframe of 2-hour (Bajer et al., 2015) . In research conducted by Chuichulcherm et al., the same soxhlet approach was utilized, where a Capsicum annuum $(1.0 \mathrm{~g})$ sample was extracted for 2 hours with $50 \mathrm{~mL}$ methanol (Chuichulcherm et al., 2013) . Though soxhlet is the most commonly used extraction technique, it has drawbacks such as greater power consumption, lower capsaicinoids yields, and longer processing times when compared to other existing extraction techniques like PLE, $\mathrm{UAE}$, and MAE. Table 2 displays these extraction results.

\subsection{Enzymatic extraction}

Enzymatic technologies have been developed to boost productivity and accuracy during the extraction of fruits (Wen et al., 2020), Several commonly available enzymes (olivex, viscozyme L, 5XAL, and peczyme) were utilized by Santamaría et al. in his research to loosen the tissues in Chili pepper and boost the extraction efficiency by 7\%, with a final retrieval of $82 \%$ of capsaicinoids (Santamaría et al., 2000) (Santamaría et al., 2000) . The processing did take place at $50^{\circ} \mathrm{C}$, needed $7 \mathrm{hrs}$ of agitation in a shaking incubator at $120 \mathrm{rpm}$, and had a chili powder-to-water ratio of 1: 50. L. Chen \& Kang, used a similar technique that included energex (primarily glucanase) and extrazyme (mostly carbohydrases and pectinase), which improved capsaicinoid yield by $33 \%$ (L. Chen \& Kang, 2013). The temperature, in this case, was kept at $43 \mathrm{C}$ for a time frame of $12 \mathrm{hrs}$, while the ratio of chili dried powder-to-water was maintained at 1: 1. Relying on the treatment approaches described above, Salgado-Roman et al developed a noncommercial enzymatic treatment based on Rhizopus nigricans enzymatic extracts (Salgado-Roman et al., 2008) At $60^{\circ} \mathrm{C}$, samples were extracted in a soxhlet apparatus together with tetrahydrofuran. Capsaicinoids had a greater yield of more than $86 \%$, indicating a much more robust cellulosic ability of this non-commercial enzymatic extract to loosen the cell membranes and enable cell decomposition.

\subsection{Pressurize liquid extraction (PLE)}

The operation of PLE is frequently carried out at high pressure and temperature, allowing for hydrophilic properties of components in the solvents while maintaining the solvent below its boiling temperature, leading to high solvent penetration into the sample cell wall (Renato et al., 2019). Several studies have used the PLE technique to isolate capsaicinoid from spicy chilies (Bajer et al., 2015; Gerardo F. Barbero et al., 2006b; Chanthai et al., 2012) . Barbero et al established a PLE process using ethanol, water, and methanol as extraction solvents at $200^{\circ} \mathrm{C}$ and 100 atm. HPLC-mass spectrometry was used to examine the results (Gerardo F. Barbero et al., 2006a) . In a study performed by Chanthai et al the capsaicinoids, Capsaicin, dihydrocapsaicin, and nordihydrocapsaicin were isolated from dried $C$. annuum specimens using the PLE technique with methanol at a temperature of $100{ }^{\circ} \mathrm{C}$ and a pressure of 1500 psi (Chanthai et al., 2012) . Following the protocols described by Bajer et al, a pressurized hot water extraction technique was utilized to recover capsaicinoids from ten chili specimens. Water was chosen as the ecologically friendly medium in this experiment. HPLC-MS was used for the quantitative analysis. HPLC-MS was used for the quantitative analysis. They also examined the extraction yield of capsaicin, dihydrocapsaicin, and nordihydrocapsaicin using several extraction procedures such as MAE, UAE, SOX, and PLE, and discovered that PLE produced the greatest yields (Bajer et al., 2015).

\subsection{Microwave-assisted extraction (MAE).}

MAE is a technology created by combining microwave and conventional solvent extraction that uses the energy

Volume 11 Issue 1, January 2022 


\section{International Journal of Science and Research (IJSR) \\ ISSN: 2319-7064 \\ SJIF (2020): 7.803}

produced by microwave radiation to heat the solvents and accelerate the speed of separation. When compared to conventional reflux and shaking flask extraction techniques, Paduano et al. found that the MAE approach tripled the capsaicinoids yield and greatly reduced the duration of extraction (Paduano et al., 2014) . Barbero et al. enhanced MAE settings for extracting capsaicinoids from raw pepper specimens. The extraction settings of $125^{\circ} \mathrm{C}$, power of 500 $\mathrm{W}$, for 5 minutes of extraction time, and $0.5 \mathrm{~g}$ of pepper dissolved in $25 \mathrm{~mL}$ of ethanol were determined to be optimal in this investigation (Gerardo F. Barbero et al., 2006b) . The experts also examined the effectiveness of regularly used techniques, like magnetic stirring, and found that MAE is a quicker process. Chuichulcherm et al compared three distinct extraction procedures: Soxhlet, UAE, and MAE, as seen on the findings confirmed that the MAE approach produced the most capsaicinoids for an extraction period of 20 minutes with moderate power consumption, whereas the soxhlet technique produced the most capsaicinoids over an extraction timeframe of 300 minutes with high power consumption. Among the three methods, the UAE approach exhibited the lowest energy usage per capsaicinoids and the lowest time of extraction (Chuichulcherm et al., 2013).

Table 1: Chemical structures of capsaicinoids

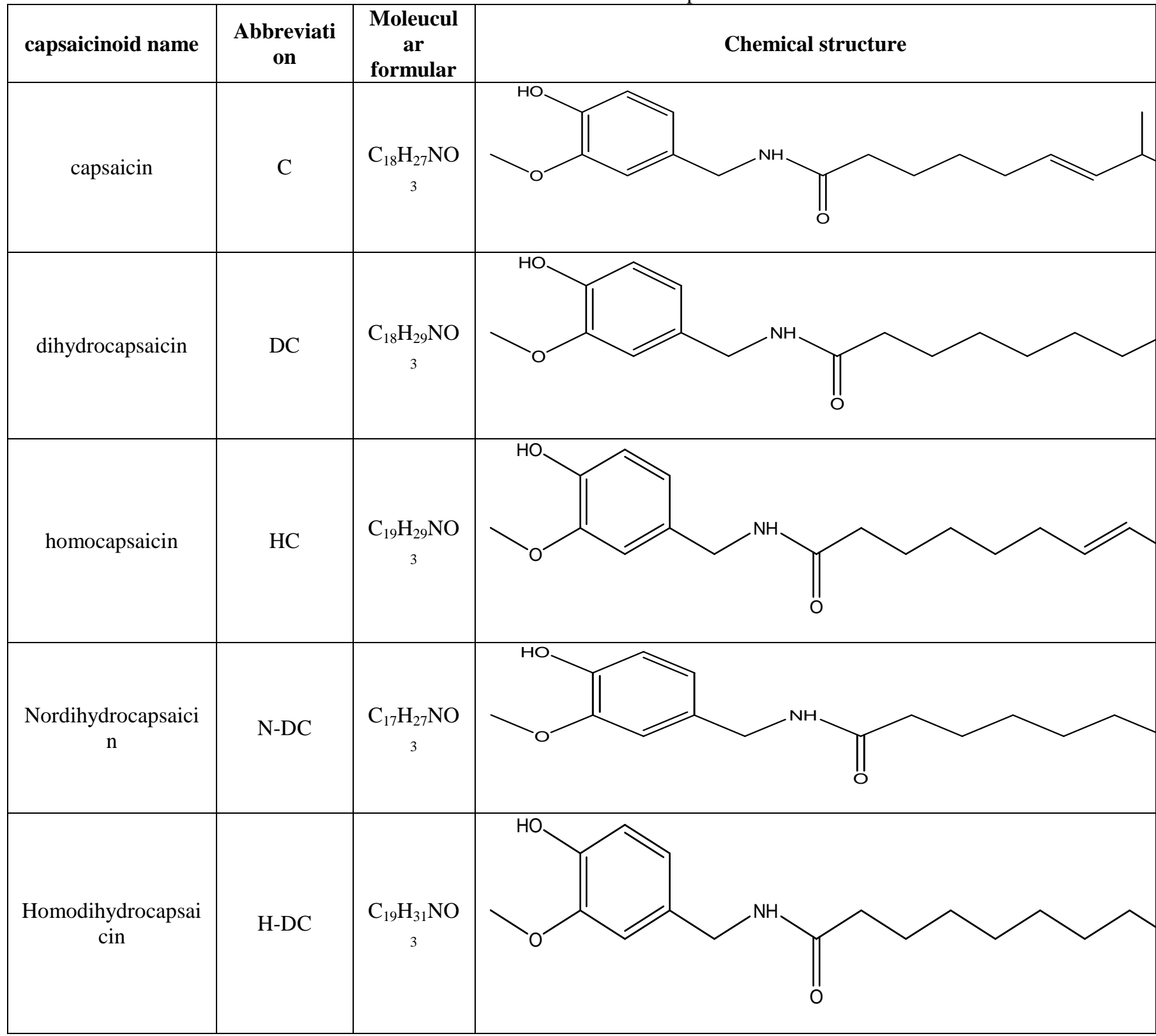

\subsection{Supercritical fluid extraction (SFE)}

Based on the principle of supercritical fluid extraction, pressure and temperature are elevated above their critical points by taking advantage of gas and liquid properties (Ciko et al., 2018). In this extraction method, carbon dioxide is a popular solvent because it's non-toxic, cheap, and safe to use (Lefebvre et al., 2021) . During the extraction process, supercritical carbon dioxide can only extract nonpolar or components of low polarity, but it can still remove polar solvents when polar co-solvents (e. g., methanol and ethanol) are employed. It is the combination of temperature and pressure that determines the selectivity of the targeted bioactive molecule in supercritical fluid during extraction (Heffernan et al., 2016) . The low critical pressure and temperature associated with carbon dioxide

Volume 11 Issue 1, January 2022 


\section{International Journal of Science and Research (IJSR) \\ ISSN: 2319-7064 \\ SJIF (2020): 7.803}

allow the preservation of bioactive molecules with little or no degradation (da Silva et al., 2016).

Santos et al recovered capsaicinoids from Capsicum Frutescensl $l$. using supercritical fluid extraction aided with carbon dioxide and ultrasound as the solvents at temperatures, pressures, and flow rates of $40{ }^{\circ} \mathrm{C}, 15 \mathrm{MPa}$, and $1.774 \times 10-3 \mathrm{~kg} / \mathrm{s}$, respectively. The ultrasonic power was set at $360 \mathrm{~W}$ for 60 minutes (Santos et al., 2015). The Supercritical fluid extraction rate significantly increased. Dias et al conducted a comparable supercritical fluid extraction test on dedo de moca pepper with $(80 \mathrm{~min}, 40 \mathrm{C}$, $25 \mathrm{MPa}$, and $600 \mathrm{~W}$ ) but without (40C, $25 \mathrm{MPa})$ ultrasound treatment. The flow rate of carbon dioxide as held constant at $1.774 \times 10^{-3} \mathrm{~kg} / \mathrm{s}$. The findings revealed that the overall production of supercritical fluid extraction was substantially improved (Dias et al., 2016) . In conclusion, the use of ultrasound may enhance the yield of capsaicinoids from supercritical fluid extraction, which could be used as an alternative to the existing extraction procedures that employ dangerous chemical solvents.

\subsection{Ultrasound-assisted extraction}

The UAE method is successful owing to the cavitation phenomena that occurs whenever an acoustic wave passes through the extraction liquid, creating power to accelerate the blending and diffusion of the liquid into the sample cell wall (Alves Filho et al., 2020) . The use of UAE has several benefits, including the temperature, decrease of solvents, and extraction time, which is critical for the recovery of heat-sensitive and volatile compounds.

Table 2: Quantification of various capsaicinoids extracted from pepper

\begin{tabular}{|c|c|c|c|c|c|c|c|c|c|c|}
\hline $\begin{array}{l}\text { Extracti } \\
\text { on } \\
\text { Method }\end{array}$ & Solvent & $\begin{array}{c}\text { Conditi } \\
\text { on }\end{array}$ & Pepper & Cap & DHC & N-DHC & $\mathrm{HC}$ & H-DHC & unit & $\begin{array}{c}\text { Referen } \\
\text { ce }\end{array}$ \\
\hline \multirow[t]{13}{*}{ Soxlet } & Methanol & $\begin{array}{c}\text { Time: } 2 \mathrm{~h} \\
\text { Pressure } \\
: 1 \mathrm{~atm}\end{array}$ & $\begin{array}{l}\text { Trinidadscorp } \\
\text { ion }\end{array}$ & $\begin{array}{c}42.83 \pm 0.4 \\
03\end{array}$ & $\begin{array}{c}18.09 \pm 0.1 \\
8\end{array}$ & $\begin{array}{c}0.42 \pm 0.0 \\
3\end{array}$ & $\mathrm{x}$ & $\mathrm{x}$ & $\begin{array}{c}\mathrm{g} / \mathrm{kg} \text { of } \\
\text { dried } \\
\text { sample }\end{array}$ & $\begin{array}{l}\text { (Bajer } \\
\text { et al., } \\
2015 \text { ) }\end{array}$ \\
\hline & & & Moruga fruit & & & & $\mathrm{x}$ & $\mathrm{x}$ & & \\
\hline & & & $\begin{array}{c}\text { Yellow } \\
\text { bedder fruit }\end{array}$ & $2.49 \pm 0.03$ & $2.53 \pm 0.09$ & $\begin{array}{c}0.29 \pm 0.0 \\
9\end{array}$ & $\mathrm{x}$ & $\mathrm{x}$ & & \\
\hline & & & Ring fire fruit & $1.74 \pm 0.06$ & $1.72 \pm 0.05$ & $\begin{array}{c}0.51 \pm 0.0 \\
2\end{array}$ & $\mathrm{x}$ & $\mathrm{x}$ & & \\
\hline & & & $\begin{array}{c}\text { Jamaican hot } \\
\text { red fruit }\end{array}$ & $2.08 \pm 0.08$ & $1.17 \pm 0.06$ & $\begin{array}{c}0.20 \pm 0.0 \\
2 \\
\end{array}$ & $\mathrm{x}$ & $\mathrm{x}$ & & \\
\hline & & & $\begin{array}{c}\text { Yellow } \\
\text { habanero fruit }\end{array}$ & $\begin{array}{c}\mathrm{O} .54 \pm 0.0 \\
3\end{array}$ & $0.41 \pm 0.02$ & $\begin{array}{c}0.027 \pm 0 . \\
01\end{array}$ & $\mathrm{x}$ & $\mathrm{x}$ & & \\
\hline & & & Tabasco fruit & $3.19 \pm 0.02$ & $2.50 \pm 0.09$ & $\begin{array}{c}0.95 \pm 0.0 \\
1\end{array}$ & $\mathrm{x}$ & $\mathrm{x}$ & & \\
\hline & & & $\begin{array}{l}\text { Bhut jolokia } \\
\text { spice }\end{array}$ & $8.53 \pm 0.07$ & $5.73 \pm 0.05$ & $\begin{array}{c}0.17 \pm 0.0 \\
2\end{array}$ & $\mathrm{x}$ & $\mathrm{x}$ & & \\
\hline & & & $\begin{array}{c}\text { Fatalii red } \\
\text { spice }\end{array}$ & $\begin{array}{c}10.64 \pm 0.0 \\
9 \\
\end{array}$ & $3.06 \pm 0.09$ & $\begin{array}{c}0.10 \pm 0.0 \\
1 \\
\end{array}$ & $\mathrm{x}$ & $\mathrm{x}$ & & \\
\hline & Ethyl acetate & $\begin{array}{l}\text { Time: } 6 \mathrm{~h} \\
\text { Temp: } \\
25^{\circ} \mathrm{C}\end{array}$ & $\begin{array}{l}\text { Malagueta } \\
\text { pepper }\end{array}$ & $2.16 \pm 0.2$ & $1.20 \pm 0.08$ & $\begin{array}{c}0.10 \pm 0.0 \\
1\end{array}$ & $\mathrm{x}$ & $\begin{array}{c}0.03 \pm 0.0 \\
03\end{array}$ & $\begin{array}{c}\mathrm{g} / \mathrm{kg} \text { of } \\
\text { dried } \\
\text { sample }\end{array}$ & $\begin{array}{c}\text { (Santos } \\
\text { et al., } \\
2015 \text { ) }\end{array}$ \\
\hline & $\begin{array}{l}\text { dichlorometh } \\
\text { ane }\end{array}$ & & & $2.27 \pm 0.03$ & $1.22 \pm 0.17$ & $\begin{array}{l}0.09 \pm 0.1 \\
5\end{array}$ & $\mathrm{x}$ & $\begin{array}{c}0.04 \pm 0.0 \\
06\end{array}$ & & \\
\hline & Ethyl acther & & & $1.76 \pm 0.12$ & $0.97 \pm 0.07$ & $\begin{array}{c}0.06 \pm 0.0 \\
03\end{array}$ & $\mathrm{x}$ & $\begin{array}{c}0.03 \pm 0.0 \\
07\end{array}$ & & \\
\hline & Hexane & & & $1.88 \pm 0.17$ & $1.05 \pm 0.09$ & $\begin{array}{c}0.09 \pm 0.0 \\
1\end{array}$ & $\mathrm{x}$ & $\begin{array}{c}0.03 \pm 0.0 \\
04\end{array}$ & & \\
\hline & & & & & & & & & & \\
\hline \multirow[t]{3}{*}{ UAE } & Methanol & \multirow{3}{*}{$\begin{array}{l}\text { Temp: } \\
50^{\circ} \mathrm{C} \\
\text { Time: } \\
\text { 10min } \\
\text { Pressure } \\
\text { : 1atm }\end{array}$} & Cayenne & $448 \pm 28$ & $265 \pm 17$ & $94 \pm 6$ & $30 \pm 1$ & $47 \pm 2$ & $\begin{array}{c}\mu \mathrm{mol} / \mathrm{k} \\
\mathrm{g} \text { of } \\
\text { fresh } \\
\text { pepper }\end{array}$ & $\begin{array}{c}\text { (G. F. } \\
\text { Barbero } \\
\text { et al., } \\
2008 \text { ) }\end{array}$ \\
\hline & & & $\begin{array}{l}\text { Bolilla } \\
\text { rehondo } \\
\text { pepper }\end{array}$ & $370 \pm 24$ & $190 \pm 11$ & $40 \pm 3$ & $\mathrm{x}$ & $20 \pm 1$ & & \\
\hline & & & $\begin{array}{c}\text { Bollila largo } \\
\text { pepper }\end{array}$ & $275 \pm 17$ & $124 \pm 7$ & $24 \pm 3$ & $\mathrm{x}$ & $14 \pm 1$ & & \\
\hline \multirow[t]{2}{*}{ SFE } & $\begin{array}{l}\text { Carbon } \\
\text { dioxide }\end{array}$ & $\begin{array}{c}\text { Temp: } \\
40^{\circ} \mathrm{C} \\
\text { Pressure } \\
: 25 \mathrm{Mpa}\end{array}$ & $\begin{array}{c}\text { Dedo de } \\
\text { moca pepper }\end{array}$ & $0.88 \pm 0.11$ & $0.37 \pm 0.05$ & $\begin{array}{c}0.06 \pm 0.0 \\
2\end{array}$ & $\begin{array}{c}0.04 \pm 0 . \\
01\end{array}$ & $\begin{array}{c}0.01 \pm 0.0 \\
0\end{array}$ & $\begin{array}{c}\mathrm{g} / \mathrm{kg} \text { of } \\
\text { raw } \\
\text { materia } \\
1 \\
\end{array}$ & $\begin{array}{l}\text { (Dias et } \\
\text { al., } \\
2016 \text { ) }\end{array}$ \\
\hline & $\begin{array}{c}\text { Carbondioxid } \\
\mathrm{e}\end{array}$ & $\begin{array}{c}\text { Temp: } \\
40^{\circ} \mathrm{C} \\
\text { Pressure } \\
: 15 \mathrm{Mpa}\end{array}$ & $\begin{array}{l}\text { Biquinho } \\
\text { pepper }\end{array}$ & $0.30 \pm 0.01$ & $\begin{array}{c}0.075 \pm 0.0 \\
07\end{array}$ & $\mathrm{x}$ & $\mathrm{x}$ & $\mathrm{x}$ & $\begin{array}{l}\mathrm{g} / \mathrm{kg} \text { of } \\
\text { dried } \\
\text { sample }\end{array}$ & $\begin{array}{c}\text { (de } \\
\text { Aguiar } \\
\text { et al., } \\
2014)\end{array}$ \\
\hline
\end{tabular}

Volume 11 Issue 1, January 2022 
International Journal of Science and Research (IJSR)

ISSN: 2319-7064

SJIF (2020): 7.803

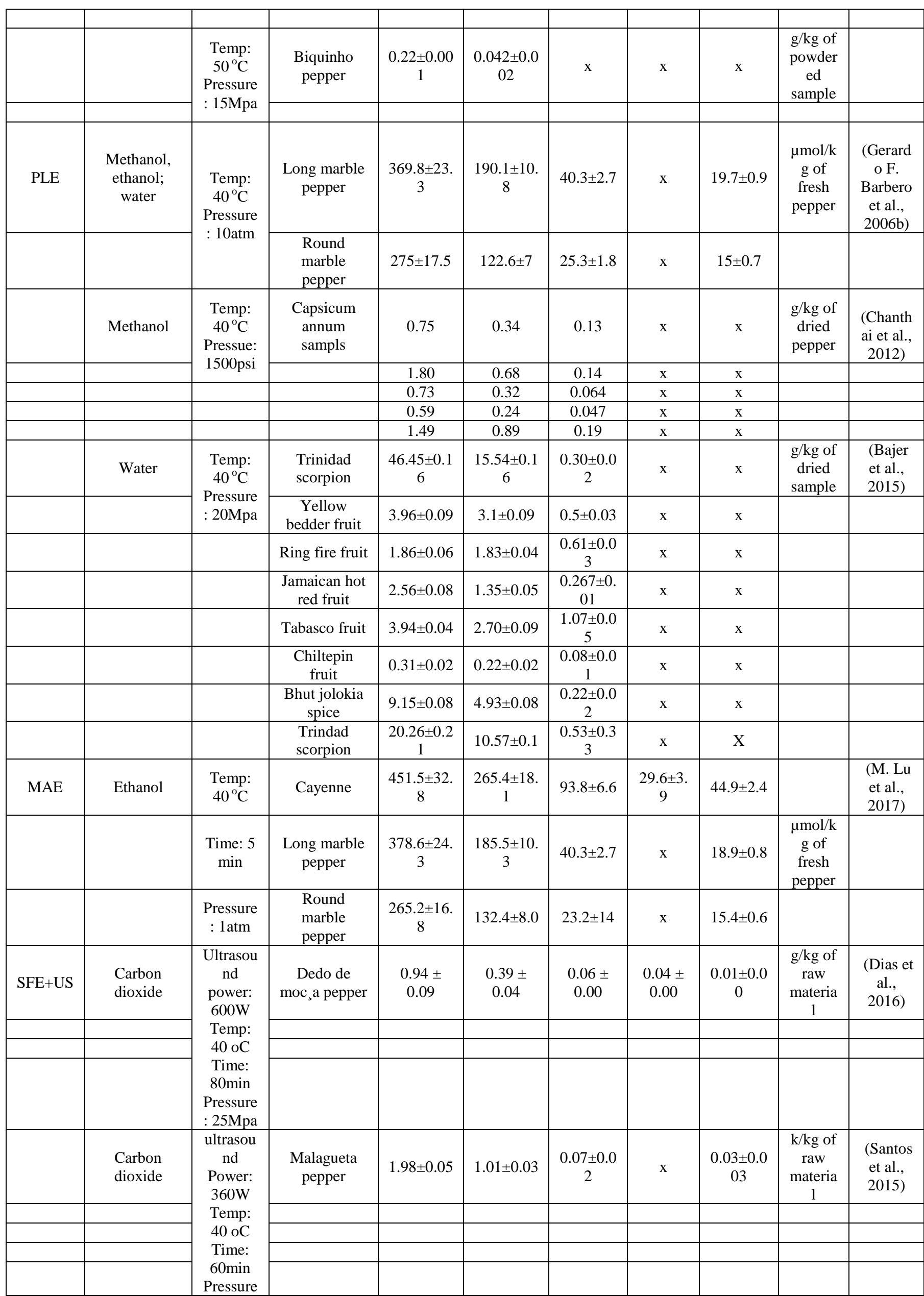

Volume 11 Issue 1, January 2022

www.ijsr.net

Licensed Under Creative Commons Attribution CC BY 
Cap: capsaicin, DHC: dihydrocapsaicin, HC: homocapsaicin, H-DHC: homodihydrocapsaicin, MAE: microwave-assisted extraction, N-DHC: nordihydrocapsaicin, SFE: supercritical fluid extraction, PLE: pressurized liquids extraction, US: ultrasound: ultrasound-assisted extraction: UAE; X: not detected.

\section{Analytical Methods}

Isolation and characterization of bioactive compounds from the pepper is a technique that has shown significant advancement in the past few years. Due to the complicated molecular structure of some compounds, little is still understood about the analysis of these antioxidants. To gain a deeper understanding of these antioxidants, robust analytical techniques are required to map the structure and size of biological compounds. Due to this, current research has focused on developing new optimization-based techniques. Choosing an appropriate quantification method will lead to more accurate findings. One of the most commonly used is liquid chromatography-mass spectrometry (LC-MS) for mass-to-charge ratio (m/z)-based detection. For detection based on a maximal absorbance peak, high-performance liquid chromatography (HPLC) linked to ultraviolet (UV) or diode-array detector (DAD) is used. Alternatively, nuclear magnetic resonance (NMR) can be used to determine its structure.

Gahungu et al used column chromatography on silica gel to extract capsaicinoids from a cultivar of chili, which they subsequently quantified using reverse phase-high performance liquid chromatography/photodiode array detection (RP-HPLC/PAD). The most abundant capsaicinoids detected were $48.632 \mathrm{mg} / \mathrm{g}$ of capsaicin and $24.162 \mathrm{mg} / \mathrm{g}$ of dihydrocapsaicin (Gahungu et al., 2011) . Al Othman et al Used HPLC to separate, identify, and quantify capsaicin and dihydrocapsaicin in red chilies, hot chilies, green peppers, green chilies, yellow peppers, and red peppers. Hot chilies had the greatest proportion of capsaicin (423 g/g) and the most pungency, while green chilies had the lowest measured content $(1 \mathrm{~g} / \mathrm{g})$, and red, yellow, and green peppers were non-pungent (Al Othman et al., 2011) . Furthermore, L. Chen et al utilized HPLC-UV to determine the existence of capsaicin in an extract of red pepper. The concentration of Capsaicin was found to be $9.48 \mathrm{mg} / \mathrm{g}$, according to the HPLC-UV chromatogram (L. Chen \& Kang, 2013) . In addition, Santos et al used HPLC-MS to identify the five primary capsaicinoids found in peppers in their investigation (Santos et al., 2015). Daood et al collected and studied several Capsicum fruits utilizing HPLC. The optimal analytical conditions were achieved with a reversed-phase apparatus, a mobile phase of-acetic acid-acetonitrile, a detector wavelength of $280 \mathrm{~nm}$ utilizing a UV detector, and a flow rate of $1.0 \mathrm{ml} / \mathrm{min}$ (Daood et al., 2015) . In place of HPLC, González-Zamora et al investigated direct spectrophotometric detection of various capsaicinoids concentrations in Chiltepin pepper. The findings revealed that comparison results obtained by HPLC and spectrophotometrically ranged from 30 to $128 \mathrm{mg}$ of capsaicinoids per g (González-Zamora et al., 2015). As a result, the spectrophotometric approach may be frequently used for total capsaicinoid analysis and quality assurance in pharmaceutical preparations, with a correlation of 0.9 .

\section{Conclusion}

This paper presents an overview of several extraction parameters which may aid in the standardisation of the operation, which is especially significant at the commercial scale. The modification of the extraction method allows for maximum yield while lowering the cost of production associated with solvent and energy consumption, hence guiding the decision for a sustainable and efficient method of producing isolates high in capsinoids. Thus, future research on effective, fast, and quick extraction technologies may hasten the process of commercialization.

\section{References}

[1] Agrawal, R. C., Wiessler, M., Hecker, E., \& Bhide, S. V. (1986). Tumour-promoting effect of chilli extract in BALB/c mice. International Journal of Cancer, 38(5), 689-695. https://doi.org/10.1002/ijc.2910380512

[2] Al Othman, Z. A., Ahmed, Y. B. H., Habila, M. A., \& Ghafar, A. A. (2011). Determination of capsaicin and dihydrocapsaicin in Capsicum fruit samples using high performance liquid chromatography. Molecules, 16(10), 8919-8929. https://doi.org/10.3390/molecules16108919

[3] Alothman, Z. A., Wabaidur, S. M., Khan, M. R., Ghafar, A. A., Habila, M. A., \& Ahmed, Y. B. H. (2012). Determination of capsaicinoids in Capsicum species using ultra performance liquid chromatographymass spectrometry. Journal of Separation Science, 35(21), https://doi.org/10.1002/jssc.201200459

[4] Alves Filho, E. G., Sousa, V. M., Rodrigues, S., de Brito, E. S., \& Fernandes, F. A. N. (2020). Green ultrasound-assisted extraction of chlorogenic acids from sweet potato peels and sonochemical hydrolysis of caffeoylquinic acids derivatives. Ultrasonics Sonochemistry, 63, 104911. https://doi.org/10.1016/j.ultsonch.2019.104911

[5] Amantini, C., Ballarini, P., Caprodossi, S., Nabissi, M., Morelli, M. B., Lucciarini, R., Cardarelli, M. A., Mammana, G., \& Santoni, G. (2009). Triggering of transient receptor potential vanilloid type 1 (TRPV1) by capsaicin induces Fas/CD95-mediated apoptosis of urothelial cancer cells in an ATM-dependent manner. Carcinogenesis, 30(8), https://doi.org/10.1093/carcin/bgp138

[6] Arora, V., Campbell, J. N., \& Chung, M. K. (2021). Fight fire with fire: Neurobiology of capsaicin-induced analgesia for chronic pain. Pharmacology and Therapeutics, 220, 107743. https://doi.org/10.1016/j.pharmthera.2020.107743

[7] Bajer, T., Bajerová, P., Kremr, D., Eisner, A., \& Ventura, K. (2015). Central composite design of pressurised hot water extraction process for extracting capsaicinoids from chili peppers. Journal of Food Composition and Analysis, 40, 32-38. https://doi.org/10.1016/j.jfca.2014.12.008

[8] Barbero, G. F., Liazid, A., Palma, M., \& Barroso, C. G.

Volume 11 Issue 1, January 2022 
(2008). Fast determination of capsaicinoids from peppers by high-performance liquid chromatography using a reversed phase monolithic column. Food Chemistry, 107(3), 1276-1282. https://doi.org/10.1016/j.foodchem.2007.06.065

[9] Barbero, Gerardo F., Palma, M., \& Barroso, C. G. (2006a). Determination of capsaicinoids in peppers by microwave-assisted extraction-high-performance liquid chromatography with fluorescence detection. Analytica Chimica Acta, 578(2), 227-233. https://doi.org/10.1016/j.aca.2006.06.074

[10] Barbero, Gerardo F., Palma, M., \& Barroso, C. G. (2006b). Pressurized liquid extraction of capsaicinoids from peppers. Journal of Agricultural and Food Chemistry, 54(9), 3231-3236. https://doi.org/10.1021/jf060021y

[11]Belvisi, M. G., \& Birrell, M. A. (2017). The emerging role of transient receptor potential channels in chronic lung disease. European Respiratory Journal, 50(2). https://doi.org/10.1183/13993003.01357-2016

[12] Braga Ferreira, L. G., Faria, J. V., dos Santos, J. P. S., \& Faria, R. X. (2020). Capsaicin: TRPV1-independent mechanisms and novel therapeutic possibilities. European Journal of Pharmacology, 887(August), 173356. https://doi.org/10.1016/j.ejphar.2020.173356

[13] Chanthai, S., Juangsamoot, J., Ruangviriyachai, C., \& Techawongstien, S. (2012). Determination of capsaicin and dihydrocapsaicin in some chilli varieties using accelerated solvent extraction associated with solidphase extraction methods and RP-HPLC-fluorescence. E-Journal of Chemistry, 9(3), 1550-1561. https://doi.org/10.1155/2012/380574

[14] Chen, K. S., Chen, P. N., Hsieh, Y. S., Lin, C. Y., Lee, Y. H., \& Chu, S. C. (2015). Capsaicin protects endothelial cells and macrophage against oxidized lowdensity lipoprotein-induced injury by direct antioxidant action. Chemico-Biological Interactions, 228, 35-45. https://doi.org/10.1016/j.cbi.2015.01.007

[15] Chen, L., \& Kang, Y. H. (2013). Anti-inflammatory and antioxidant activities of red pepper (Capsicum annuum L.) stalk extracts: Comparison of pericarp and placenta extracts. Journal of Functional Foods, 5(4), 1724-1731. https://doi.org/10.1016/j.jff.2013.07.018

[16] Chuichulcherm, S., Prommakort, S., Srinophakun, P., \& Thanapimmetha, A. (2013). Optimization of capsaicin purification from Capsicum frutescens Linn. with column chromatography using Taguchi design. Industrial Crops and Products, 44, 473-479. https://doi.org/10.1016/j.indcrop.2012.10.007

[17] Ciko, A. M., Jokić, S., Šubarić, D., \& Jerković, I. (2018). Overview on the application of modern methods for the extraction of bioactive compounds from marine macroalgae. Marine Drugs, 16(10). https://doi.org/10.3390/md16100348

[18] da Silva, R. P. F. F., Rocha-Santos, T. A. P., \& Duarte, A. C. (2016). Supercritical fluid extraction of bioactive compounds. TrAC - Trends in Analytical Chemistry, 76, 40-51. https://doi.org/10.1016/j.trac.2015.11.013

[19] Daood, H. G., Halasz, G., Palotás, G., Palotás, G., Bodai, Z., \& Helyes, L. (2015). HPLC determination of capsaicinoids with cross-linked C18 column and bufferfree eluent. Journal of Chromatographic Science, 53(1), 135-143. https://doi.org/10.1093/chromsci/bmu030
[20] de Aguiar, A. C., dos Santos, P., Coutinho, J. P., Barbero, G. F., Godoy, H. T., \& Martínez, J. (2014). Supercritical fluid extraction and low pressure extraction of Biquinho pepper (Capsicum chinense). LWT - Food Science and Technology, 59(2P2), 12391246. https://doi.org/10.1016/j.lwt.2014.06.014

[21]Dias, A. L. B., Arroio Sergio, C. S., Santos, P., Barbero, G. F., Rezende, C. A., \& Martínez, J. (2016). Effect of ultrasound on the supercritical $\mathrm{CO} 2$ extraction of bioactive compounds from dedo de moça pepper (Capsicum baccatum L. var. pendulum). Ultrasonics Sonochemistry, 31, 284-294. https://doi.org/10.1016/j.ultsonch.2016.01.013

[22] Gahungu, A., Ruganintwali, E., Karangwa, E., Zhang, X., \& Mukunzi, D. (2011). Volatile compounds and capsaicinoid content of fresh hot peppers (Capsicum Chinense) scotch bonnet variety at red stage. Advance Journal of Food Science and Technology, 3(3), 211218.

[23] González-Zamora, A., Sierra-Campos, E., PérezMorales, R., Vázquez-Vázquez, C., Gallegos-Robles, M. A., López-Martínez, J. D., \& García-Hernández, J. L. (2015). Measurement of capsaicinoids in chiltepin hot pepper: A comparison study between spectrophotometric method and high performance liquid chromatography analysis. Journal of Chemistry, 2015. https://doi.org/10.1155/2015/709150

[24] Heffernan, N., Smyth, T. J., FitzGerald, R. J., VilaSoler, A., Mendiola, J., Ibáñez, E., \& Brunton, N. P. (2016). Comparison of extraction methods for selected carotenoids from macroalgae and the assessment of their seasonal/spatial variation. Innovative Food Science and Emerging Technologies, 37, 221-228. https://doi.org/10.1016/j.ifset.2016.06.004

[25] Jang, K. H., Chang, Y. H., Kim, D., Oh, K., Oh, U., \& Shin, J. (2008). New Polyunsaturated Fatty Acid Amides Isolated from the Seeds of Zanthoxylum piperitum. 31(5), 569-572. https://doi.org/10.1007/s12272-001-1194-5

[26] Lefebvre, T., Destandau, E., \& Lesellier, E. (2021). Selective extraction of bioactive compounds from plants using recent extraction techniques: A review. Journal of Chromatography A, 1635, 461770. https://doi.org/10.1016/j.chroma.2020.461770

[27] Lopez-Carrillo, L., Hernandez-Avila, M., \& Dubrow, R. (1994). A case-control study of chili pepper consumption and gastric cancer in Mexico. American Journal of Epidemiology, 139(3), 263-271.

[28] Lu, H. F., Chen, Y. L., Yang, J. S., Yang, Y. Y., Liu, J. Y., Hsu, S. C., Lai, K. C., \& Chung, J. G. (2010). Antitumor activity of capsaicin on human colon cancer cells in vitro and colo 205 tumor xenografts in vivo. Journal of Agricultural and Food Chemistry, 58(24), 12999-13005. https://doi.org/10.1021/jf103335w

[29]Lu, M., Ho, C. T., \& Huang, Q. (2017). Extraction, bioavailability, and bioefficacy of capsaicinoids. Journal of Food and Drug Analysis, 25(1), 27-36. https://doi.org/10.1016/j.jfda.2016.10.023

[30] Nagabhushan, M., \& Bhide, S. V. (1986). Nonmutagenicity of Curcumin and its Antimutagenic Action Versus Chili and Capsaicin. Nutrition and Cancer, 8(3), 201-210. https://doi.org/10.1080/01635588609513894 
[31] Nagy, Z., Daood, H., Koncsek, A., Molnár, H., \& Helyes, L. (2017). The simultaneous determination of capsaicinoids, tocopherols, and carotenoids in pungent pepper powder. Journal of Liquid Chromatography and Related Technologies, 40(4), 199-209. https://doi.org/10.1080/10826076.2017.1297722

[32] Ng, C. M., \& Reuter, W. M. (2015). Analysis of Capsaicin and Dihydrocapsaicin in Chili Peppers Using the PerkinElmer Altus HPLC System with PDA Detection. 3-7.

[33] Paduano, A., Caporaso, N., Santini, A., \& Sacchi, R. (2014). Microwave and Ultrasound-Assisted Extraction of Capsaicinoids From Chili Peppers (Capsicum annuum L.) in Flavored Olive Oil. Journal of Food Research, 3(4), 51. https://doi.org/10.5539/jfr.v3n4p51

[34] Patowary, P., Pathak, M. P., Zaman, K., Raju, P. S., \& Chattopadhyay, P. (2017). Research progress of capsaicin responses to various pharmacological challenges. Biomedicine and Pharmacotherapy, 96(November), https://doi.org/10.1016/j.biopha.2017.11.124

[35] Peña-Alvarez, A., Alvarado, L. A., \& Vera-Avila, L. E. (2012). Analysis of capsaicin and dihydrocapsaicin in hot peppers by ultrasound assisted extraction followed by gas chromatography-mass spectrometry. Instrumentation Science and Technology, 40(5), 429440. https://doi.org/10.1080/10739149.2012.679719

[36] Renato, A., Mazzutti, S., Suzana, K., Vitali, L., Regina, S., \& Ferreira, S. (2019). Optimization of green PLE method applied for the recovery of antioxidant compounds from buriti ( Mauritia flexuosa L.) shell. Food Chemistry, 298(June), 125061. https://doi.org/10.1016/j.foodchem.2019.125061

[37] Salgado-Roman, M., Botello-Álvarez, E., RicoMartínez, R., Jiménez-Islas, H., Cárdenas-Manríquez, M., \& Navarrete-Bolaños, J. L. (2008). Enzymatic treatment to improve extraction of capsaicinoids and carotenoids from chili (capsicum annuum) fruits. Journal of Agricultural and Food Chemistry, 56(21), 10012-10018. https://doi.org/10.1021/jf801823m

[38] Santamaría, R. I., Reyes-Duarte, M. D., Bárzana, E., Fernando, D., Gama, F. M., Mota, M., \& LópezMunguía, A. (2000). Selective enzyme-mediated extraction of capsaicinoids and carotenoids from chili guajillo puya (Capsicum annuum L.) using ethanol as solvent. Journal of Agricultural and Food Chemistry, 48(7), 3063-3067. https://doi.org/10.1021/jf991242p

[39] Santos, P., Aguiar, A. C., Barbero, G. F., Rezende, C. A., \& Martínez, J. (2015). Supercritical carbon dioxide extraction of capsaicinoids from malagueta pepper (Capsicum frutescens L.) assisted by ultrasound. Ultrasonics Sonochemistry, 22, 78-88. https://doi.org/10.1016/j.ultsonch.2014.05.001

[40] Satya Prasad, N., Raghavendra, R., Lokesh, B. R., \& Akhilender Naidu, K. (2004). Spice phenolics inhibit human PMNL 5-lipoxygenase. Prostaglandins Leukotrienes and Essential Fatty Acids, 70(6), 521-528. https://doi.org/10.1016/j.plefa.2003.11.006

[41] Seca, A. M. L., \& Pinto, D. C. G. A. (2018). Overview on the antihypertensive and anti-obesity effects of secondary metabolites from seaweeds. Marine Drugs, 16(7). https://doi.org/10.3390/md16070237

[42] Shin, Y. H., Namkoong, E., Choi, S., Bae, J. S., Jin, M.,
Hwang, S. M., Arote, R., Choi, S. Y., \& Park, K. (2013). Capsaicin regulates the NF- $\kappa B$ pathway in salivary gland inflammation. Journal of Dental Research, 92(6), 547-552. https://doi.org/10.1177/0022034513487376

[43] Slack, J. P. (2016). Molecular Pharmacology of Chemesthesis. Chemosensory Transduction: The Detection of Odors, Tastes, and Other Chemostimuli, 375-391. https://doi.org/10.1016/B978-0-12-8016947.00021-4

[44] Stoica, R., Moscovici, M., Tomulescu, C., \& Băbeanu, N. (2016). Extraction and analytical methods of capsaicinoids - a review. Scientific Bulletin. Series F. Biotechnologies, 20(January), 93-98.

[45] Wen, L., Zhang, Z., Sun, D. W., Sivagnanam, S. P., \& Tiwari, B. K. (2020). Combination of emerging technologies for the extraction of bioactive compounds. Critical Reviews in Food Science and Nutrition, 60(11), 1826-1841. https://doi.org/10.1080/10408398.2019.1602823

[46] Xiang, Q., Guo, W., Tang, X., Cui, S., Zhang, F., Liu, X., Zhao, J., Zhang, H., Mao, B., \& Chen, W. (2021). Capsaicin - the spicy ingredient of chili peppers: A review of the gastrointestinal effects and mechanisms. Trends in Food Science and Technology, 116(August), 755-765. https://doi.org/10.1016/j.tifs.2021.08.034

[47]Zhang, D., Sun, X., Battino, M., Wei, X., Shi, J., Zhao, L., Liu, S., Xiao, J., Shi, B., \& Zou, X. (2021). A comparative overview on chili pepper (capsicum genus) and sichuan pepper (zanthoxylum genus): From pungent spices to pharma-foods. Trends in Food Science and Technology, 117(October 2020), 148-162. https://doi.org/10.1016/j.tifs.2021.03.004 